\title{
Review and reassessment of hazards owing to volcano-glacier interactions in Colombia
}

\author{
Christian HUGGEL, ${ }^{1}$ Jorge Luis CEBALLOS, ${ }^{2}$ Bernardo PULGARÍN, ${ }^{3}$ Jair RAMÍREZ, ${ }^{3}$ \\ Jean-Claude THOURET ${ }^{4}$
}

\author{
${ }^{1}$ Glaciology and Geomorphodynamics Group, Department of Geography, University of Zurich, 8057 Zurich, Switzerland \\ E-mail: chuggel@geo.unizh.ch \\ ${ }^{2}$ Instituto de Meteorología, Hidrología y Estudios Ambientales, Bogotá, Colombia \\ ${ }^{3}$ Instituto Colombiano de Geología y Minería, Bogotá, Colombia \\ ${ }^{4}$ Laboratoire Magmas et Volcans UMR 6524 CNRS, Université Blaise-Pascal, Clermont-Ferrand, France
}

\begin{abstract}
The Cordillera Central in Colombia hosts four important glacier-clad volcanoes, namely Nevado del Ruiz, Nevado de Santa Isabel, Nevado del Tolima and Nevado del Huila. Public and scientific attention has been focused on volcano-glacier hazards in Colombia and worldwide by the 1985 Nevado del Ruiz/Armero catastrophe, the world's largest volcano-glacier disaster. Important volcanological and glaciological studies were undertaken after 1985. However, recent decades have brought strong changes in ice mass extent, volume and structure as a result of atmospheric warming. Population has grown and with it the sizes of numerous communities located around the volcanoes. This study reviews and reassesses the current conditions of and changes in the glaciers, the interaction processes between ice and volcanic activity and the resulting hazards. Results show a considerable hazard potential from Nevados del Ruiz, Tolima and Huila. Explosive activity within environments of snow and ice as well as non-eruption-related mass movements induced by unstable slopes, or steep and fractured glaciers, can produce avalanches that are likely to be transformed into highly mobile debris flows. Such events can have severe consequences for the downstream communities. Integrated monitoring strategies are therefore essential for early detection of emerging activity that may result in hazardous volcano-ice interaction. Corresponding efforts are currently being strengthened within the framework of international programmes.
\end{abstract}

\section{INTRODUCTION}

Glacier-clad active volcanoes in Colombia are located along the north-south trending Cordillera Central. Nevado del Ruiz, Nevado de Santa Isabel, Nevado del Tolima and Nevado del Huila extend over a distance of $\sim 250 \mathrm{~km}$ and peaks range from $\sim 4960-5360 \mathrm{~m}$ a.s.l.

Scientific and public attention has been focused on volcano-glacier hazards in Colombia and worldwide since the 1985 Nevado del Ruiz catastrophe. The town of Armero was buried by lahars resulting from pyroclastic density currents and related snow/ice melt and debris flow generation in the summit region of Nevado del Ruiz (Naranjo and others, 1986). Over 20000 people died in Armero. The tragedy of Armero is one of the major volcanic disasters in history and by far the largest involving volcano-glacier interaction. Another major disaster occurred on the slopes of Nevado del Huila in 1994, although not directly linked to volcano-glacier interaction. An earthquake of magnitude 6.4 (Richter scale) triggered numerous landslides in the Rio Páez catchment, and subsequently a debris flow was fed from multiple detachment sites and killed about 1000 persons (Scott and others, 2001). Consequently, it was recognized that the volcanic chain of the Cordillera Central is a potential site for additional catastrophes.

Following the 1985 disaster, important volcanological and glaciological studies were undertaken with a primary focus on Nevado del Ruiz (e.g. Calvache, 1990; Parra and Cepeda, 1990; Pierson and others, 1990; Thouret, 1990; Thouret and others, 1995; Nuñez Tello, 1996). The eruption history of the volcanoes was reconstructed, the ice extent assessed, and preliminary hazard maps were drawn.

Now, twenty years after the 1985 catastrophe, glaciers on the Colombian volcanoes have experienced significant changes in terms of extent, volume and structure due to atmospheric warming (Ceballos and others, 2006). The Colombian glaciers are examples of the small and decreasing number of ice masses in the inner tropics. In the last decades, a particularly pronounced retreat was observed for glaciers in both the inner and outer tropics (Kaser, 1999). In Colombia, glaciers have lost $50 \%$ or more of their surface area in the past 50 years, and from 10 to $50 \%$ in the last 15 years (Ceballos and others, 2006). Population, on the other hand, has continuously grown within numerous communities around the volcanoes. The vulnerability to volcano-glacier hazards has thus increased over the past years.

This paper provides a review of the current knowledge of the volcanoes of Nevados del Ruiz, Santa Isabel, Tolima and Huila based on volcanological studies to date. Glaciological conditions on these volcanoes are assessed considering recent studies and ongoing monitoring programmes. Based on this, and glacier-volcano interactions observed in the past, we evaluate the most important processes, provide quantitative estimates of potential mass flows and describe corresponding hazards.

The terminology for rapid mass movements used in this paper corresponds to that proposed by Pierson and Scott (1985) and Scott and others (2001). Debris flows are rapidly moving flows of saturated debris (from clay to boulder size). Debris avalanches are mainly grain flows, which may be 


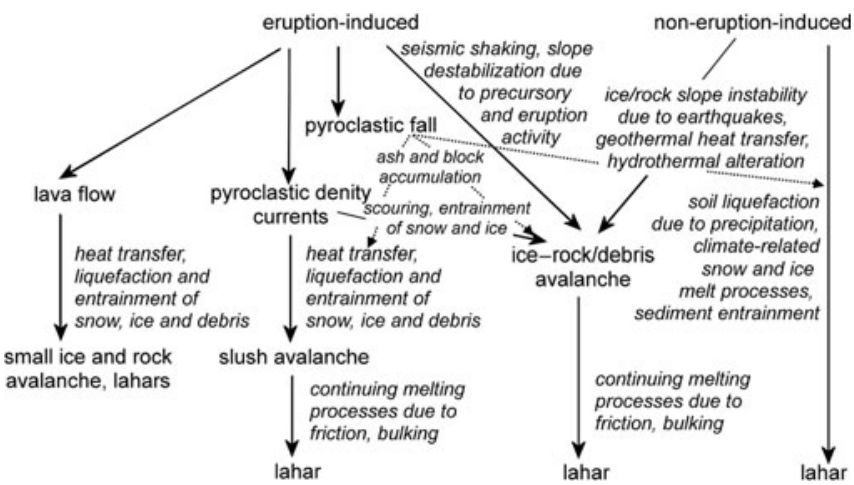

Fig. 1. Simplified scheme of possible interactions between ice/snow and volcanic activity relevant to mass movement generation at the ice-capped volcanoes in Colombia. Arrows spreading from pyroclastic fall deposits are dotted because such deposits are not directly triggering mass movements, but facilitate mobilization and the subsequent onset of flow.

only partially saturated. Transformation of debris avalanche to debris flow is common, i.e. when defined channels are entered and the flow becomes saturated by water. The term lahar refers to volcanic debris flows and can include the transformation to hyperconcentrated streamflow. These types of flows can be related or unrelated to volcanic eruptions (Fig. 1). Pyroclastic density current describes dilute (surge) to high-concentration (flow) currents related to volcanic eruptions.

\section{NEVADO DEL RUIZ Volcano}

Nevado del Ruiz is the northernmost glacier-clad volcano of the Andean chain (Fig. 2). It is $5320 \mathrm{~m}$ a.s.I. and is a composite stratovolcano with a flat summit and an ice cap. Arenas crater, with a diameter of $850 \mathrm{~m}$ and a depth of $250 \mathrm{~m}$, was the vent for the 13 November 1985 eruption. Like the neighbouring volcanoes of the Ruiz-Tolima massif, Nevado del Ruiz is topographically constrained by the Magdalena valley in the east and the Cauca valley in the west. Tectonically, Ruiz is located at the intersection of four faults, some of which are still active.

Ruiz is by far the best studied among Colombia's glacierclad volcanoes, due to the tragic disaster in 1985 that prompted a series of important studies. Many of these studies are collected in a special publication (Willliams, 1990a, b). The Quaternary and Holocene eruption history is fairly well known. Thouret and others (1990a) identified three main eruption periods in the $1.8 \mathrm{Ma}$ long history of Nevado del Ruiz. At the end of the earliest period of activity, which was characterized by a partial collapse and formation of a caldera ( 1.0 to $0.8 \mathrm{Ma}$ ago), a stratovolcano was built with deposits including massive pyroclastic density currents. The present edifice of the Ruiz volcano is a product of the activity over the last 150000 years represented by a constructive phase featuring emplacement of a series of domes and thick lava flows of andesite and dacite magma.

During the last 11000 years, 12 eruption stages, probably each with multiple eruptions, are identified. Processes included tephra fallout, pyroclastic density currents, multiple slope failures with debris avalanches and lahars, and interaction with the ice cap (Thouret and others, 1990a).

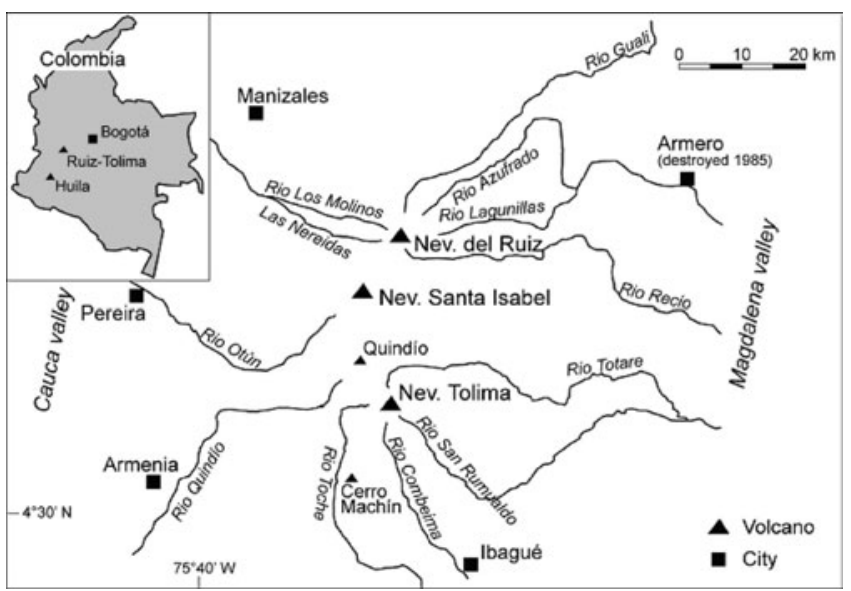

Fig. 2. Schematic map of the Ruiz-Tolima volcanic area showing main drainages from the Nevados del Ruiz, Santa Isabel and Tolima volcanoes.

Debris avalanches and lahars particularly affected the Azufrado and Lagunillas rivers. Three historic events are recorded: 1595, 1845 and 1985. The 1595 event was characterized by explosive eruptions and debris avalanches transforming into lahars (Pierson and others, 1990). In 1845, a small phreato-magmatic eruption took place, claiming 1000 lives as populated areas were inundated in a similar but more extensive way as in 1985. In terms of lahar volumes, the 1845 event was the largest (about $300 \times$ $10^{6} \mathrm{~m}^{3}$ of total lahar volume), followed by the 1595 and the 1985 lahars (Thouret and others, 1990b). Since 1985, fumarolic activity has been continuously observed at the Arenas crater, and various hot spring locations were detected around the volcano.

\section{Glaciers}

The ice cap on Nevado del Ruiz can be divided into about eight drainage basins and corresponding outlet glaciers. Lagunillas, Recio and Guali-Molinos glaciers, which drain to the corresponding river systems, comprise most of the ice mass. The ice cap has been strongly affected by glacier retreat in recent decades, with glacier area reduced by more than $50 \%$ in the last 40 years (Fig. 3). Estimates of the preand post-1985 eruption glacier area vary between 19$25 \mathrm{~km}^{2}$ and $17-21 \mathrm{~km}^{2}$, respectively (Thouret, 1990; Ceballos and others, 2006). During the two decades following 1985 , there has been another $40-50 \%$ loss of the glacier area with measurements from 2002 and 2003 showing an area of only $10.3 \mathrm{~km}^{2}$ (Table 1 ). Ground penetrating radar studies performed in 1999 revealed a maximum ice thickness of $190 \mathrm{~m}$ with an average thickness of $47 \mathrm{~m}$ (Ceballos and others, 2006). Taking into consideration that the glacier has been continually thinning since 1999, an upper estimate for the total ice volume of $484 \times 10^{6} \mathrm{~m}^{3}$ can be derived for 2003. Based on an average ice density of $0.85 \mathrm{~g} \mathrm{~cm}^{-3}$ (including the top snow and firn layers), a water equivalent of $411 \times 10^{6} \mathrm{~m}^{3}$ is calculated. Single glacier tongues that reached elevations of $4500-4600 \mathrm{~m}$ a.s.I. in 1986 have now retreated to $4800-4900 \mathrm{~m}$ a.s.l. Also, erosion by pyroclastic density currents generated by the 1985 eruption significantly reduced the size of several outlet glaciers, in particular those of Lagunillas and Azufrado glaciers (Fig. 3). These glaciers have remained in a fractured, 


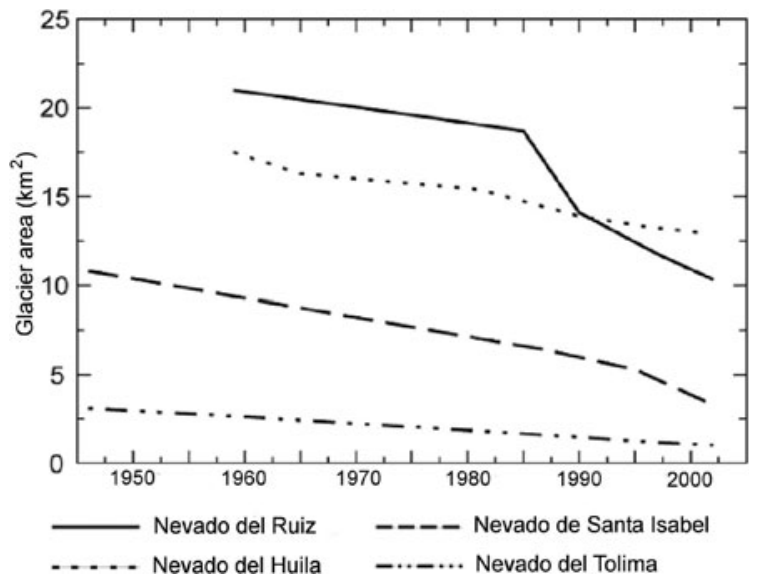

Fig. 3. Reduction of glacier surface area in recent decades for the four glacier-capped volcanoes in Colombia. Note acceleration in retreat rates since the mid-1980s for Nevado del Ruiz, related to the 1985 eruption.

unstable state since the eruption but no significant ice avalanches have been observed.

\section{Interactions and hazards}

Interactions between volcanic activity and the ice caps are the key to the Ruiz paradox, which is that a small eruption could lead to one of the world's largest volcanic disasters in history. Based on the extensive studies related to the 1985 disaster, processes and associated hazards of volcano-ice interactions can be readily assessed for Nevado del Ruiz. The main processes identified are: pyroclastic density currents that are able to generate large amounts of meltwater if hot debris is mechanically mixed with snow and ice (Pierson and others, 1990; Walder, 2000); slush avalanches induced by sudden loading of snow and firn on steep and unstable slopes (Thouret, 1990); and rock and ice avalanches triggered by seismic shaking, percolating meltwater and sudden increase of shear stress due to overriding pyroclastic density currents (Pierson and others, 1990; Fig. 1). The low density and cohesion of snow facilitate easy scouring and entrainment, and were probably responsible for generating much of the 1985 meltwater (Thouret, 1990). Dilute flows and avalanches rapidly transformed into debris flows in the river channels by entrainment of sediment. The total volume of lahars reaching downstream areas was about $90 \times 10^{6} \mathrm{~m}^{3}$, mean peak velocities ranged from $5-15 \mathrm{~m} \mathrm{~s}^{-1}$, and a peak discharge of $48000 \mathrm{~m}^{3} \mathrm{~s}^{-1}$ was reached in the Azufrado valley $9 \mathrm{~km}$ from the source (Pierson and others, 1990). The river systems mainly affected by lahars were the Lagunillas, Azufrado and Guali in the east to northeast, and Nereidas/Molinos in the west. The travel time of lahars, an important consideration for early warning, was slightly more than one hour for the first $50 \mathrm{~km}$ (Azufrado). Armero was reached in little over 2 hours while the most distant areas affected by lahars, more than $100 \mathrm{~km}$ away from the source, were reached in about 4 hours.

The Holocene eruption history of Ruiz provides evidence that lahars are common phenomena and the most serious and far-reaching hazard (Thouret and others, 1990b). Lahar volumes ranged from about 90 (1985) to 300 (1845) million $\mathrm{m}^{3}$. The volume of the 1595 eruption-related lahars is intermediate but not exactly known (Herd, 1982; Pierson and others, 1990). In addition to meltwater-induced lahars generated by the interaction of snow and ice with hot eruption products, floods from water stored within the ice or along the river channels require consideration. The lahars in 1845, for example, were probably enlarged by a flood released from the breaching of a dam formed by a contemporaneous debris avalanche (Thouret and others, 1990b).

It is estimated that about $10 \%$ of the ice volume was removed during the 1985 event (Pierson and others, 1990; Thouret, 1990). Since then, the glaciers have significantly retreated. The reduced area and the decreased mass of ice lying on steep topography suggest that an eruption similar in magnitude to that of 1985 (VEI = 3) would not mobilize more than $10 \%$ of the present ice volume. A larger eruption, however, could easily interact with a greater ice volume. Under present conditions, a $10 \%$ water equivalent of the total ice mass on Ruiz would amount to $\sim 40 \times 10^{6} \mathrm{~m}^{3}$ of water. For an estimate of the combined lahar volume we assume that $30 \%$ of this water would not be directly available for lahar generation (water trapped and diluted in the ice and sediment; Thouret, 1990). For the 1985 lahars, the water concentration (by volume) of the initial lahars was estimated to be 0.6-0.8 (Pierson and others, 1990). The initial lahar volume for present conditions would therefore be $35-47 \times 10^{6} \mathrm{~m}^{3}$. Based on bulking factors of $2-4$ observed in 1985 (Pierson and others, 1990), we estimate the combined lahar volume to reach distal deposition zones to be $70-188 \times 10^{6} \mathrm{~m}^{3}$ (Table 1). This means that the magnitude of lahars could be similar to those in 1985, but could also be larger in spite of the reduced ice volume. This is not necessarily an inconsistency because the critical processes determining the final lahar volume (i.e. eruption magnitude, formation of initial lahars and bulking factors) have some range of variation and could be more vigorous than those observed in 1985, as other case studies have shown (e.g. Scott and others, 2005). The range of potential lahar volumes indicates that downstream areas would consequently be severely affected again.

In addition to hazards related to eruption activity, noneruption processes must be taken into consideration, including rock/ice avalanches due to earthquakes and flank failures, particularly in the northeast Azufrado sector where evidence exists for multiple flank failures (Thouret and others, 1990b; Fig. 1). Further details on current conditions and hazards on Nevado del Ruiz are provided by Thouret and others (2007).

\section{NEVADO DE SANTA ISABEL}

\section{Volcano}

Nevado de Santa Isabel is the third highest volcano $(4965 \mathrm{~m}$ a.s.l.) on the Pliocene to early Pleistocene Ruiz-Tolima plateau $\left(1500 \mathrm{~km}^{2}\right)$. It is located $10 \mathrm{~km}$ south of Nevado del Ruiz and $18 \mathrm{~km}$ north of Nevado del Tolima (Fig. 2). Unlike its two neighbouring volcanoes, Nevado de Santa Isabel does not have a plateau ice cap; it is rather constructed as a north-south trending ridge with a number of domes and two main peaks. It is drained by the rivers Otún and Claro to the west and Totarito towards the Magdalena valley in the east. The volcanic history of Nevado de Santa Isabel is not as well known than that of its neighbours. Three domes named Norte (north), Centro (centre) and Sur (south), of Pleistocene age and andesite composition, were identified in the summit 
Table 1. Glacier surface areas, estimated ice volumes and derived potential lahar characteristics of the ice-capped volcanoes in the Cordillera Central in Colombia

\begin{tabular}{lcccc}
\hline & Nevado del Ruiz & Nevado de Santa Isabel & Nevado del Tolima & Nevado del Huila \\
\hline Glacier surface area $\left(\mathrm{km}^{2}\right)$ & $10.3(2003)$ & $3.3(2002)$ & $1.04(2002)$ & $12.95(2001)$ \\
Ice volume $\left(10^{6} \mathrm{~m}^{3}\right)$ & 484 & 198 & 73 & 648 \\
Water equivalent $\left(10^{6} \mathrm{~m}^{3}\right)$ & 411 & 168 & 62 & 550 \\
Total lahar volume $\left(10^{6} \mathrm{~m}^{3}\right)$ & $70-190$ & $30-80^{*}$ & $10-30$ & $100-260$ \\
Main drainages affected & Azufrado, Lagunillas, & & Combeima, Toche, & Páez, Símbola \\
Possible max. reach of lahars $(\mathrm{km})$ & Guali, Nereidas/Molinos & & $\sim 100$ & $>150$ \\
\hline
\end{tabular}

*Based on an average ice density of $0.85 \mathrm{~g} \mathrm{~cm}^{-3}$.

'Based on a $10 \%$ ice melt scenario (by thermal interaction and avalanching) with $70 \%$ water available for initial lahar generation and bulking factors of $2-4$ for distal lahars.

tahar volume calculation for Nevado de Santa Isabel is theoretical since corresponding trigger processes are unlikely to occur under present conditions.

area. No historic activity is known to date but lava flows originating from the aforementioned domes with the same age and composition were found. More recent blocky lavas were dated 2800, 5500, 6750 and 7450 years BP (Méndez, 1997). In the summit area beneath the lava flows, there are pyroclastic density current deposits from the northern dome that consist of ash and pumice. The main eruption products are restricted to a distance of $5-8 \mathrm{~km}$ from the summit.

\section{Glaciers}

In 2002, the ice mass on Nevado de Santa Isabel extended over an area of $3.3 \mathrm{~km}^{2}$ and could be divided into 19 different drainage basins each terminating in small outlet glaciers. According to ground penetrating radar profiles taken in north-south and east-west directions in 2000, the maximum ice thickness in the summit region is $103 \mathrm{~m}$. Towards the ice margin, values range from $\sim 20-80 \mathrm{~m}$. Taking an average thickness of $60 \mathrm{~m}$, we calculate a total ice volume of $198 \times 10^{6} \mathrm{~m}^{3}$, which is equivalent to $168 \times$ $10^{6} \mathrm{~m}^{3}$ of water (based on an average ice density of $0.85 \mathrm{~g} \mathrm{~cm}^{-3}$ ) (Table 1). Ice volume estimates made by Linder (1991) for 1987 were considerably lower but no direct ice thickness measurements were available at that time. Glacier fluctuations on Nevado de Santa Isabel have been monitored regularly during the last 15-17 years. During this period, the steady retreat of outlet glaciers has been recorded almost on an annual basis. Measurements of the ice surface area go back to 1946 and are based on aerial photographs and more recently on satellite images. In the last decades the glaciers on Nevado de Santa Isabel have, in fact, experienced one of the most dramatic shrinkages of any glaciers in Colombia. Since 1850 (ice surface reconstructed according to the position of Little Ice Age moraines) the glaciers have been reduced by almost $90 \%$ in terms of area. The retreat rate has accelerated in the last few decades; in $<20$ years the area covered by glaciers has been reduced by about 50\% (Ceballos and others, 2006; Fig. 3). In the same period, glacier margins retreated by as much as $250 \mathrm{~m}$.

The observed rise of the equilibrium line altitude (ELA) on Nevado del Santa Isabel is about $190 \pm 30 \mathrm{~m}$ for the period 1850 to 2002 and $95 \pm 30 \mathrm{~m}$ for 1959 to 2002 (Baumann, 2006). If this rise in ELA resulted only from elevation of surface temperature, the corresponding temperature rise would be $1.2 \pm 0.2^{\circ} \mathrm{C}$ and $0.6 \pm 0.2^{\circ} \mathrm{C}$ for 1850 to 2002 and 1959 to 2002 , respectively (with a lapse rate of $0.65^{\circ} \mathrm{C}$ per $100 \mathrm{~m}$ ), implying an accelerated rate of ELA rise over the last
40 years by a factor of $\sim 2$. A direct comparison with measured temperature changes is difficult since high-mountain temperature records, in particular long-term, are generally rare throughout Colombia. One of the few meteorological stations (Las Brisas) is located $12 \mathrm{~km}$ north of Nevado de Santa Isabel and $5 \mathrm{~km}$ from Nevado del Ruiz at $4150 \mathrm{~m}$ a.s.l. Measurements from the mid-1980s to mid-1990s indicate a temperature rise of about $0.5^{\circ} \mathrm{C}$. Another station in the Sierra Nevada del Cocuy in northeast Colombia at $3716 \mathrm{~m}$ a.s.l. shows an increase in temperature of about $1^{\circ} \mathrm{C}$ from 1974 to 2000. Application of a simple parameterization scheme assuming a step-wise change in mass balance (Haeberli and Hoelzle, 1995) and a mass balance gradient of $1.9 \mathrm{~m}$ per $100 \mathrm{~m}$ results in a mass balance deficit of $0.4-0.6 \mathrm{~m} \mathrm{a}^{-1}$ water equivalent for 1959 to 2002.

\section{Interactions and hazards}

The past eruption activity of Nevado de Santa Isabel has been predominantly effusive. Heat transfer through the bases and sides of lava flows is generally not efficient enough to melt the amount of snow and ice required to generate lahars or floods (Major and Newhall, 1989). Snow and ice melted by subaerial lava flows is usually converted to steam. The process of steam production without generation of any significant lahar has been observed on Llaima and Villarica volcanoes in Chile in 1979 and 1984, respectively (Moreno and others, 1981; Gonzalez-Ferran, 1985). On both volcanoes, small mixed rock and ice avalanches were produced as the lava flow chilled, fragmented and mixed debris with snow and ice (Fig. 1). Llaima and Villarica volcanoes, however, have a much larger ice cover than Nevado de Santa Isabel where lava flows can only travel a maximum distance of 500-700 $\mathrm{m}$ on snow and ice. Therefore, generation of significant avalanches or meltwater by advancing lava flows is unlikely on Nevado de Santa Isabel. Pyroclastic density currents are far more effective at melting ice and snow than lava flows. At Nevado de Santa Isabel, pyroclastic density currents could result from collapse of domes or lava flows. In the past, however, pyroclastic density currents have been documented as rare occurrences, and had a limited reach of only $5 \mathrm{~km}$ from the vent. Dome collapse could also involve avalanches, which would probably entrain ice and snow.

At present, there is no indication of renewed activity at Nevado de Santa Isabel, and therefore eruption-induced hazards are not likely in the near future. A more likely 


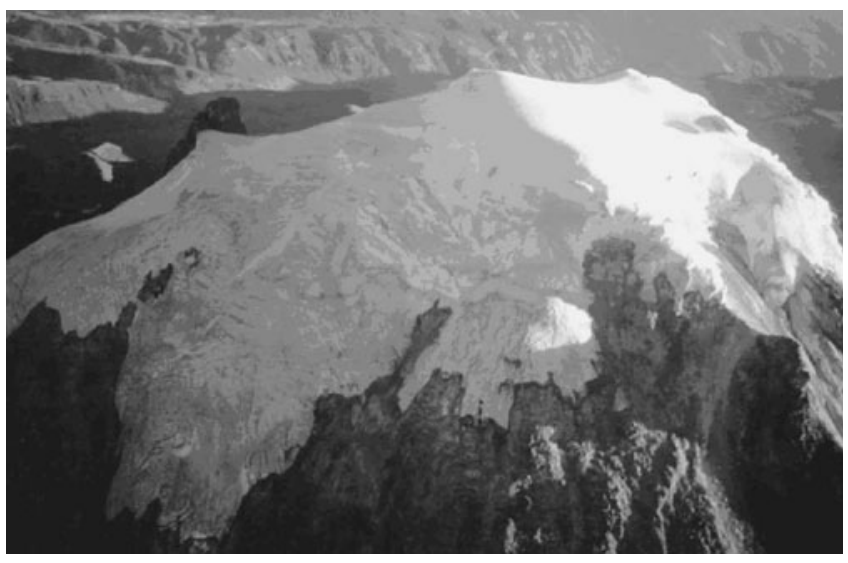

Fig. 4. The ice cap of Nevado del Tolima with Combeima outlet glacier. The steep slopes with strongly fractured ice and unstable rock faces are clearly visible.

scenario involves lahars resulting from snow/ice melt events generated by rainstorms sufficiently large to mobilize ash and other unconsolidated sediment to form a debris flow. In view of the rare occurrence of such mass movements in historic times, the massive retreat of glaciers on Nevado de Santa Isabel in recent decades and the existence of attenuation zones in the run-out of the stream channels before reaching populated areas, we consider that there is only a limited hazard of a major lahar with potential for downstream destruction. Furthermore, we have no indication of an increased thermal heat flux on Nevado de Santa Isabel that could cause melting at the base of the glacier and induce glacier instabilities.

\section{NEVADO DEL TOLIMA}

\section{Volcano}

Nevado del Tolima is part of the basaltic andesite and andesite Ruiz-Tolima volcanic massif, but is offset $15 \mathrm{~km}$ to the southeast from the main volcanic range. The $5280 \mathrm{~m}$ a.s.I. Tolima is composed of a cluster of lava domes and extrusions nested in an inferred summit caldera of late Pleistocene age (Thouret and others, 1995). The lava domes are underlain by a dissected stratovolcano. Holocene glacial deposits and products from pyroclastic density currents form the top of the mountain. Four major valley systems drain Nevado del Tolima: Rio Totaré (north), Rio San Rumualdo (east), Rio Combeima (south) and Rio Toche (west) (Fig. 2). Due to the offset from the main mountain range, all these rivers eventually drain to the Rio Magdalena valley in the east. The closest and most populated settlements are located along the Rio Combeima, with the provincial capital of lbagué ( 400000 inhabitants) situated $27 \mathrm{~km}$ from the summit of Nevado del Tolima.

Thouret and others (1995) distinguished four major sequences of edifice growth and destruction during the past 1.4 Ma. A caldera collapse occurred in late Pleistocene times. From 16000 years BP, several eruption stages with explosive characteristics have been recorded, e.g. a violent crater opening between 16200 and 14000 years BP, a large plinian eruption between 13000 and 12300 years BP and another smaller plinian eruption $\sim 3600$ years BP. Several deposits of pyroclastic density currents in the late and middle Holocene are known, with some indicating probable interactions of magma and ice. The total volume of pyroclastic deposits from the Holocene is estimated to be $\sim 2.5 \mathrm{~km}^{3}$ (Thouret and others, 1995). During this time, small-volume rock falls also occurred, destroying part of the northeast flank of the summit. In late pre-historical and historical times, only eruptions of moderate size (VEI 2-3) have taken place. Activity was recorded a few times in the 18th and 19th centuries, the last in 1943 (VEI 2). The remoteness of the volcano and limited visibility due to convective tropical cloud coverage are, however, the main reasons for the lack of detailed documentation of these events (Krueger, 1927; Kraus, 1944). Predominantly fumarolic activity has been observed in the last few decades, concentrated on the southwest area of the crater (Cepeda and others, 1988). The existence of hot springs on the northeast and southern slopes, and weak seismicity captured by INGEOMINAS (Instituto Colombiano de Geología y Minería) seismic stations, are further signs of current volcanic unrest.

\section{Glaciers}

The ice cap on Nevado del Tolima extends into four main glacial basins draining the above-mentioned rivers (Fig. 4). The extent of the ice cap at the end of the last Ice Age (14000-12000years BP) was in the range of $35 \mathrm{~km}^{2}$ (Thouret and others, 1995). Volcanic eruptions during this period likely involved significant magma-ice interactions. At the end of the Little Ice Age $(\sim 1850)$, the ice extent had decreased to $8.6 \mathrm{~km}^{2}$ with terminus positions no lower than $4300 \mathrm{~m}$ a.s.I. The last 150 years, on Nevado del Tolima as elsewhere, have been characterized by rapid ice retreat: from $2.7 \mathrm{~km}^{2}$ in 1958 , to $1.6 \mathrm{~km}^{2}$ in 1987 , to $1.2 \mathrm{~km}^{2}$ in 1997 and eventually $1.04 \mathrm{~km}^{2}$ in 2002 (Fig. 3).

Ground penetrating radar measurements in 1998 found a maximum ice thickness of $175 \mathrm{~m}$ and an average thickness of $70 \mathrm{~m}$ yielding an estimated total ice volume of $73 \times$ $10^{6} \mathrm{~m}^{3}$. Assuming an average ice density of $0.85 \mathrm{~g} \mathrm{~cm}^{-3}$, a water equivalent of $62 \times 10^{6} \mathrm{~m}^{3}$ can be derived. The large ice thickness is remarkable in view of the small ice surface area and is related to the crater morphology of the summit, which facilitates ice accumulation. The ice quickly thins from the massive ice cap towards the heavily crevassed outlet glaciers (Fig. 4). Ongoing atmospheric warming will continue to affect the outlet glaciers with further reduction in ice extent. The related impact on the summit ice cap will result in a reduction of ice thickness. However, due to the large thickness, ice will remain much longer on Nevado del Tolima than what the small area of $1 \mathrm{~km}^{2}$ and linear extrapolation of glacier area reduction would suggest.

\section{Interactions and hazards}

The past extent of the ice cap on Nevado del Tolima makes the occurrence of volcano-ice interactions a very likely scenario for eruption activity in the late Pleistocene and Holocene. Based on the geological record and the current conditions, the most important volcano-ice processes in terms of hazards are the generation of large debris flows due to scouring and melting of ice by pyroclastic density currents, and ice and rock avalanches which can also be transformed into more mobile debris flows.

The likelihood of future eruptions may be seen in view of the average occurrence interval of 2000-4000 years between major eruptions and the current period of about 17003600 years since the last major eruption. A future eruption 
may well be of explosive character as suggested by the explosive history of the volcano and the magmatic evolution (dacite and andesite) observed in the Holocene eruption products (Thouret and others, 1995).

In spite of the rapid reduction in ice surface area in the past decades, a large volume of ice remains on the summit of Nevado del Tolima. A $10 \%$ melting of the ice volume (as was the case during the 1985 Nevado del Ruiz eruption) could produce an initial lahar volume of 5.4-7.2 $\times 10^{6} \mathrm{~m}^{3}$, based on a $70 \%$ availability of meltwater and an initial water concentration of $0.6-0.8$. Total combined lahar volumes reaching downstream areas could then be 11$29 \times 10^{6} \mathrm{~m}^{3}$ (based on downstream bulking rates of 2 to 4 ) (Table 1). Lahar volume could additionally be enhanced by water input from precipitation, tributary rivers and melt from seasonal snow cover. Although Rio Toche and Rio Totare have rather low gradients, there is substantial potential for bulking because of the presence of unconsolidated deposits of pumice and ash. In these river systems, deposits from mid-Holocene lahars of 6-10m thickness were found as far away as $60-70 \mathrm{~km}$ from the source (Thouret and others, 1995). Medium-magnitude lahars would probably attenuate by energy dissipation in the flat sections of the streams.

The topography of the Rio Combeima catchment, which drains $60 \%$ of the total ice surface, is characterized by a steep and deep valley, and hence lahars would bulk more quickly and travel at higher speeds. The city of Ibagué, located along Rio Combeima at a distance of $27 \mathrm{~km}$ and a vertical drop of $3600 \mathrm{~m}$ from the Nevado del Tolima summit, could be reached by lahars in about 40-60 min (Cepeda and others, 1988; Thouret and others, 1995) while the upstream settlement of Juntas could be reached in less than $30 \mathrm{~min}$. The fact that Ibagué is built on lahar deposits confirms the vulnerability of the city to high-magnitude lahars from Nevado del Tolima.

An additional hazard on Nevado del Tolima stems from ice and rock avalanches. Factors that contribute to these types of mass movement are the strongly crevassed structure and the steep slope gradient of the outlet glaciers. An eruption of $\mathrm{VEI} \geq 3$ could trigger major ice-rock avalanches by pyroclastic current impact and eruption seismicity, which subsequently could transform into more mobile debris flows (Scott and others, 2001) and affect the downstream communities of the Combeima catchment.

Ice-rock avalanches can also occur in times of no eruptions. The region is seismically highly active, and consequently earthquakes could effectively destabilize the glaciers on Nevado del Tolima. Furthermore, geothermal heat flow or fumarolic activity could lead to an increased melt at the ice-bedrock interface and thus reduce resistance forces, eventually resulting to failure. Similar processes are thought to be responsible for the high frequency of ice-rock avalanches of up to $30 \times 10^{6} \mathrm{~m}^{3}$ on Iliamna volcano, Alaska (Caplan-Auerbach and Huggel, 2007).

\section{NEVADO DEL HUILA Volcano}

Nevado del Huila is the southernmost glacier-clad volcano of Colombia's Cordillera Central. Remoteness, topography and guerrilla activity make access difficult, which is the main reason why there are few studies of this volcano. Our understanding of the formation and history of Nevado del

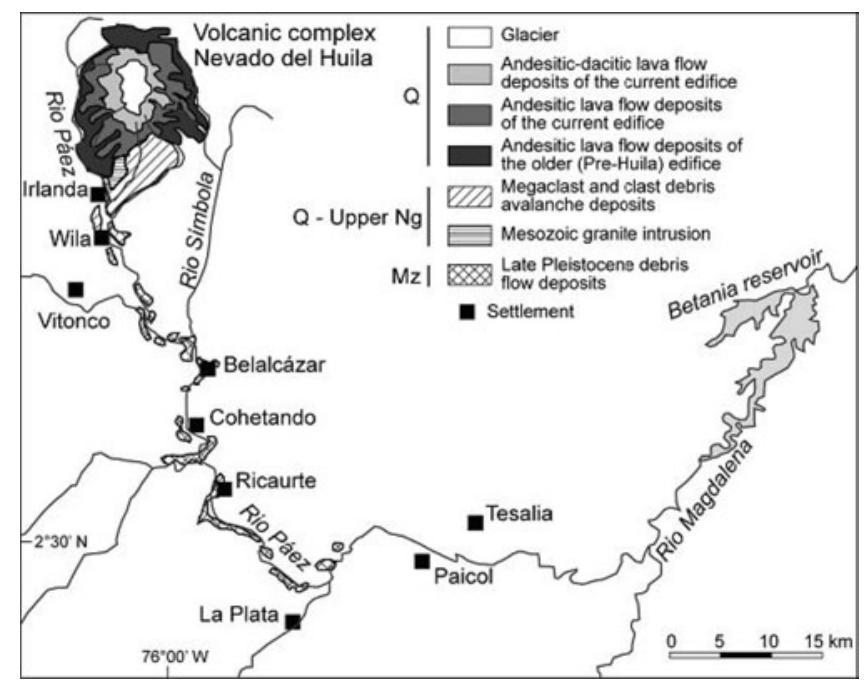

Fig. 5. Schematic map of the Nevado del Huila and the main drainage of the Páez river. Also shown is the distribution of volcanic formations and the prehistoric debris avalanche deposits. Geologic time scale: Q: Quaternary; Q-Upper Ng: Quaternary to Upper Neogene; Mz: Mesozoic.

Huila thus remains limited, but recent investigations have yielded new information (Pulgarín and others, 2001). Nevado del Huila is a stratovolcano and located at the intersection of the states of Cauca, Huila and Tolima. The plan-view shape of the volcano is elliptical, with major and minor axes of 16 and $11 \mathrm{~km}$, respectively. The maximum elevation is $5365 \mathrm{~m}$ a.s.l. There is no clear evidence of a crater; instead the peaks named Norte, Cresta, Central and Sur form the top of the edifice. The drainage system of Nevado del Huila is somewhat peculiar since the main rivers Páez and Símbola both drain to the south (Fig. 5). The Nevado del Huila volcanic complex was formed by two edifices, the older one (Pre-Huila) with a series of andesitic lavas that extended up to $15 \mathrm{~km}$. During the period of the current edifice (Huila) andesitic to dacitic lavas were produced, along with small pyroclastic density currents generated by collapse or explosion of domes. The most recent volcanic products were characterized by a higher viscosity. It is notable that in the late Pleistocene the volcano suffered a partial collapse of the southern flank causing a major debris avalanche with an estimated volume of $5.4 \mathrm{~km}^{3}$ and covering an area of $36 \mathrm{~km}^{2}$ down the Páez river (Pulgarín, 2003). The flank collapse was facilitated by the reduced strength of hydrothermally altered material.

Nevado del Huila has had no recorded eruption activity in historic times. Fumarolic activity, however, has been known for the last 400 years, mainly on the glaciated area of the Central and Norte peaks. Hot springs are observed at the western flank of the volcano at the limit of Nevadas glacier and further downstream from El Mayor glacier. Seismic activity has been recorded since 1986, with a continuous record since 1993 at the INGEOMINAS volcano observatory in Popayán. Seismic events of volcanic-tectonic origin with magnitude less than 2.5 take place along a southwestnortheast trend. Earthquakes occur at depth (up to $8 \mathrm{~km}$ ) and more superficially (less than $5 \mathrm{~km}$ ) in the upper part of the edifice. The seismic network currently consists of four 


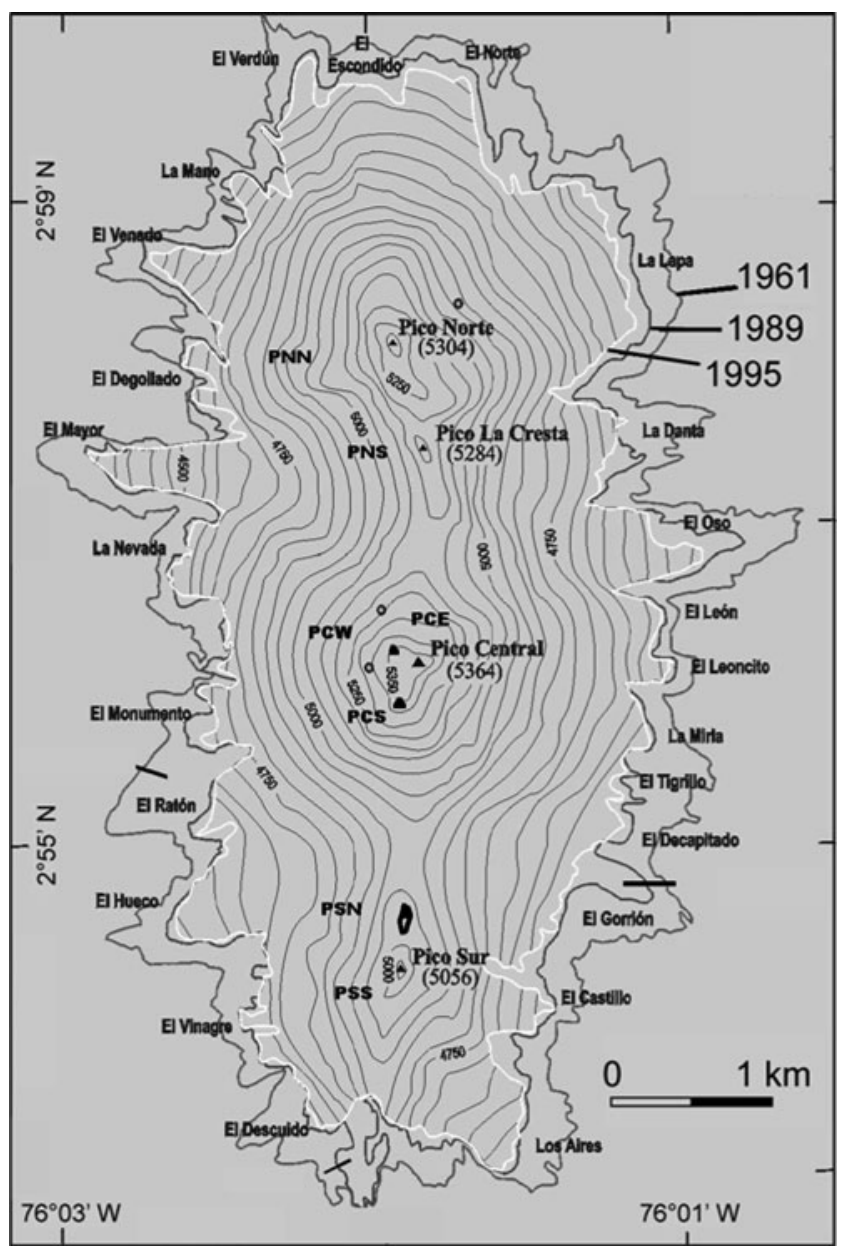

Fig. 6. Map of the ice cap on Nevado del Huila. The glacier outlines correspond to ice extents in 1961, 1989 and 1995 (white lines). Circles indicate areas of fumarolic activity. Outlet glaciers exposed to the north, west and south feed Rio Páez; those exposed to the east feed Rio Símbola.

stations, of which two are located within $3 \mathrm{~km}$ of the summit, close to the glacier terminus.

\section{Glaciers}

The ice mass on Nevado del Huila is developed on four peaks along a north-south extension with glacier tongues descending towards the west and east (Fig. 6). The glaciers, in particular towards the termini, are steeply inclined and highly crevassed. Those tongues extending furthest downstream (El Mayor, El Oso and El Venado) reached an altitude between 4160 and $4430 \mathrm{~m}$ a.s.I. in 1995. In general, the glaciers on Nevado del Huila are relatively unstudied. Pulgarín and others (1996) provided the most important information in terms of geometry, extent and recent changes. The reduction of the glaciated area between 1960 and 2000 was $\sim 25 \%$ (Ceballos and others, 2006). The area decreased from $13.9 \mathrm{~km}^{2}$ in 1990 to $13.3 \mathrm{~km}^{2}$ in 1995 and $12.95 \mathrm{~km}^{2}$ in 2001 (Fig. 3). The glacier tongues receded comparatively moderately; El Mayor, for instance, from $4053 \mathrm{~m}$ a.s.l. in 1961 to $4163 \mathrm{~m}$ a.s.I. in 1995 and El Oso from $4040 \mathrm{~m}$ a.s.I. to $4432 \mathrm{~m}$ a.s.l. in the same period.

Ice thicknesses have not been measured on Huila but if we assume a similar average ice thickness as on Nevado del Ruiz $(50 \mathrm{~m})$, the 2001 ice volume can be estimated at

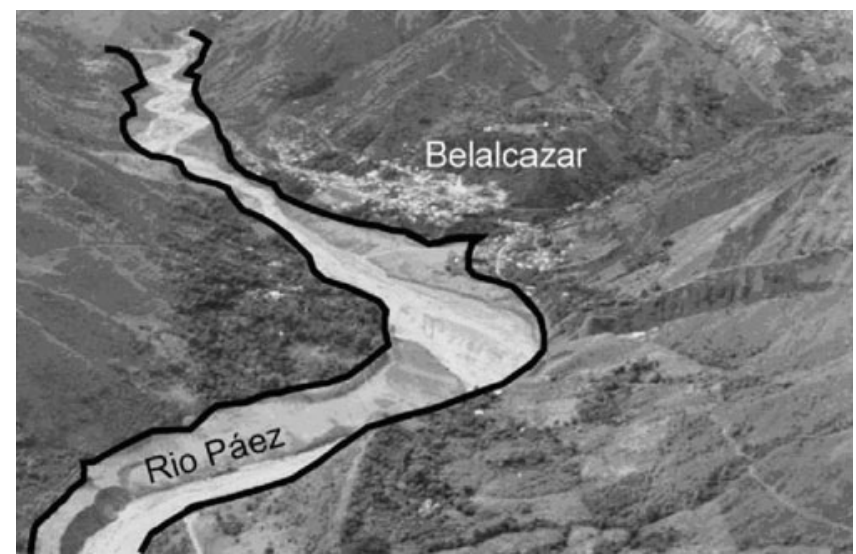

Fig. 7. Effects of the 1994 debris flow from Nevado del Huila in the Páez river at the town of Belalcázar, where flow heights reached over $20 \mathrm{~m}$. Trimlines of the 1994 flow are indicated. (Photograph courtesy of H. Cepeda.)

$648 \times 10^{6} \mathrm{~m}^{3}\left(550 \times 10^{6} \mathrm{~m}^{3}\right.$ water equivalent based on a density of $0.85 \mathrm{~g} \mathrm{~cm}^{-3}$ ). Thinning of the ice thickness, however, has been measured for the last 45 years. Average annual thinning during this period has been $0.43 \mathrm{~m}$, with a total average annual loss of ice of $\sim 10 \times 10^{6} \mathrm{~m}^{3}$ and an increasing rate of loss in more recent years (Pulgarín and others, 1996). A crude linear extrapolation of this trend would doom glaciers on Nevado del Huila to extinction around 2070.

\section{Interactions and hazards}

The geologic and historic record highlights debris avalanches and related debris flows as a serious potential hazard. Most notable was the 1994 event in which a magnitude 6.4 earthquake triggered a large number of landslides ( 3000) and small debris avalanches which coalesced into a debris flow that descended the Páez river at inundation heights of $40 \mathrm{~m}$ and maximum velocities of $25 \mathrm{~m} \mathrm{~s}^{-1}$. It caused the death of about 1000 people and massive damage (Scott and others, 2001; Pulgarín, 2003; Fig. 7). Although this catastrophe was not related to volcano-ice interactions, we suggest that it draws a realistic picture of hazards with triggering mechanisms that could well originate at the icecovered areas of Nevado del Huila.

Several factors affect the evaluation of potential volcanogenic hazards on Nevado del Huila. The volcanic history is poorly known and characteristic magnitude and periods of eruption are thus difficult to assess. The tendency towards higher magma viscosity of the most recent volcanic products and identification in the mid-1990s of pyroclastic deposits (Pulgarín and Correa, 1997) suggest that explosive activity cannot be excluded in the future. The large ice mass on Nevado del Huila bears a very significant amount of water (equivalent) potentially available for generation of mass flows. Steep topography, the fractured ice structure, high seismicity and potential geothermally induced melting at the ice-bedrock interface render the glaciers prone to instability. Several zones of hydrothermally altered rock enhance the potential for slope failure. Consequently, as the 1994 disaster showed, the population along the Páez river is highly vulnerable. High-magnitude mass movements could furthermore affect the Betania reservoir dam (used for 
hydropower generation) at a distance of more than $150 \mathrm{~km}$ from the source areas (Table 1).

\section{CONCLUSIONS AND PERSPECTIVES}

Glaciers on active volcanoes in Colombia have receded strongly in recent decades, with an accelerating trend in the last years. Glaciers with significant volumes of ice are, nevertheless, still present on the Nevados del Ruiz, Tolima, Huila and Santa Isabel. Even for Nevado del Tolima, with the least extensive ice cap, the thickness of up to $175 \mathrm{~m}$ makes the summit ice cap an important hazard element with potential volcano-ice interactions.

The current review has shown that Nevados del Ruiz and Tolima both have a high hazard potential. On Ruiz, conditions clearly remain conducive to a repetition of events comparable in magnitude to the 1985 lahars. Tolima bears about one-seventh the ice volume as Ruiz, but is potentially more explosive. Given the steep topography and the exposed downstream populations on the east to south flanks, we consider this volcano a major hazard. Mass movements associated with Nevado de Santa Isabel and its ice cap have a rather limited reach under current conditions. Assessment of hazards on Nevado del Huila is presently still fraught with uncertainties resulting from a limited knowledge of the volcano's history. Effusive activity seems to have been dominant, but there are indications of an increase towards higher explosiveness. Based on prehistoric mass movement records, the 1994 debris flow disaster, the existence of unstable slopes and large, steep and fractured glaciers, we propose that ice, rock or debris avalanches likely transforming into more mobile debris flows are the main hazard on Huila, with potentially devastating consequences for downstream communities. To summarize, we can state that all ice-capped volcanoes in Colombia, with the exception of Santa Isabel, pose a significant hazard to people and structures.

Integrated monitoring strategies are fundamental for early detection of emerging processes that may result in hazardous volcano-ice interaction on these volcanoes. The existing network of seismic stations is an important tool for the detection of volcanic unrest but it should be enlarged in the future. Restricted physical access to some of the volcanoes suggests remote sensing techniques should be employed for regular observations, particularly with regard to the rapidly changing ice caps. In view of the need for hazard prevention efforts, Colombian and Swiss government research institutions have recently initiated a programme to mitigate hazards related to Nevados del Tolima and Huila. The effective increase in safety for the population at risk shall be achieved by a comprehensive assessment of mass movement processes and the installation and operation of monitoring and early warning systems, as well as information and education campaigns on a participatory basis with communities.

\section{ACKNOWLEDGEMENTS}

We are indebted to the Swiss Agency for Development and Cooperation and the Swiss State Secretariat for Economic Affairs for support and facilitation of the studies on glaciers and volcanoes in Colombia. We would also like to thank the editors, T. Thordarsson and J. Smellie, and the two reviewers, S. Fagents and J. White, for their comments, which significantly improved the manuscript.

\section{REFERENCES}

Baumann, S. 2006. Aufbau eines gletscherinventars für Kolumbien und abschätzung glaziologischer parameter. (MSc thesis, Technischen Universität München.)

Calvache, M.L. 1990. Pyroclastic deposits of the November 13, 1985 eruption of Nevado del Ruiz volcano, Colombia. J. Volcan. Geotherm. Res., 41(1-4), 67-78.

Caplan-Auerbach, J. and C. Huggel. 2007. Precursory seismicity associated with frequent, large ice avalanches on Iliamna Volcano, Alaska. J. Glaciol., 53(180), 128-140.

Ceballos, J.L. and 6 others. 2006. Fast shrinkage of tropical glaciers in Colombia. Ann. Glaciol., 43, 194-201.

Cepeda, H., A. Murcia, J.-C. Thouret and M. Rossi. 1988. Mapa preliminar de amenaza volcánica potencial del Nevado del Tolima, Colombia. Medellín, INGEOMINAS.

Gonzalez-Ferran, O. 1985. Description of volcanic events-Chile. SEAN Bull., 10(1), 3.

Haeberli, W. and M. Hoelzle. 1995. Application of inventory data for estimating characteristics of and regional climate-change effects on mountain glaciers: a pilot study with the European Alps. Ann. Glaciol., 21, 206-212.

Herd, D.G. 1982. Glacial and volcanic geology of Ruiz-Tolima volcanic complex Cordillera central, Colombia. Publ. Geol. Especiales INGEOMINAS, 8, 1-48.

Kaser, G. 1999. A review of the modern fluctuations of tropical glaciers. Global Planet. Change, 22(1-4), 93-103.

Kraus, E. 1944. Relatos de un excursionista por las cimas nevadas de nuestras cordilleras. Bol. Soc. Geogr. Colomb., I(3), 331-335.

Krueger, E. 1927. Eine Besteigung Tolimas. Z. Volcanol., 10(3), 155-158.

Linder, W. 1991. Klimatisch und eruptionsbedingte eismassenverluste am Nevado del Ruiz, Kolumbien, während der letzten 50 Jahre. Eine untersuchung auf der basis digitaler höhenmodelle. (PhD thesis, Universität Hannover.)

Major, J.J. and C.G. Newhall. 1989. Snow and ice perturbation during historical volcanic eruptions and the formation of lahars and floods. A global review. Bull. Volcanol., 52, $1-27$.

Méndez, R. 1997. Atlas de los volcanes activos en Colombia. INGEOMINAS, Manizales

Moreno, H., O. Gonzales-Ferran and P. Riffo. 1981. Descriptions of volcanic eruptions-Chile. Bull. Volcanol. Erupt., 19, 76.

Naranjo, J.L., H. Sigurdsson, S.N. Carey and W.G. Fritz. 1986. Eruption of the Nevado del Ruiz volcano, Colombia, 13 November, 1985: Tephra fall and lahars. Science, 233, 961-963.

Nuñez Tello, A. 1996. Mapa geol'gico, department del Tolima. Bogatá, INGEOMINAS.

Parra, E. and H. Cepeda. 1990. Volcanic hazard maps of the Nevado del Ruiz volcano, Colombia. J. Volcan. Geotherm. Res., 42(1-2), 117-127.

Pierson, T.C. and K.M. Scott. 1985. Downstream dilution of a lahar: transition from debris flow to hyperconcentrated streamflow. Water Resour. Res., 21(10), 1211-1524.

Pierson, T.C., R.J. Janda, J.-C. Thouret and C.A. Borrero. 1990. Perturbation and melting of snow and ice by the 13 November 1985 eruption of Nevado del Ruiz, Colombia, and consequent mobilization, flow, and deposition of lahars. J. Volcan. Geotherm. Res., 41(1-4), 17-66.

Pulgarín, B. 2003. Mapa de amenaza por un flujo de escombros de gran volumen, simulado sobre el valle de Río Páez. Popayán, INGEOMINAS

Pulgarín, B. and A. Correa. 1997. Dep'sitos fragmentarios no consolidados sobre eledificio del Complejo Volcánico Nevado del Huila. Popayán, INGEOMINAS.

Pulgarín, B., E. Jordan and W. Linder. 1996. Nevado del Huila (Colombia): Cambio glaciar entre 1961 y 1995. In Memorias VII Congreso Colombiano de Geologia, Tome I. Ingeominas. Santafé de Bogotá, 440-451. 
Pulgarín, B., A.M. Correa, H. Cepeda and E. Ancochea. 2001. Aspectos geol'gicos del complejo volcánico Nevado del Huila $(\mathrm{CVNH})$. Popayán, INGEOMINAS.

Scott, K.M., J.L. Macías, J.A. Naranjo, S. Rodriguez, and J.P. McGeehin. 2001. Catastrophic debris flows transformed from landslides in volcanic terrains: mobility, hazard assessment and mitigation strategies. USGS Professional Paper, 1630. US Geological Survey.

Scott, K.M., J.W. Vallance, N. Kerle, J.L. Macías, W. Strauch and G. Devoli. 2005. Catastrophic precipitation-triggered lahar at Casita volcano, Nicaragua: occurrence, bulking and transformation. Earth Surf. Proc. Land., 30(1), 59-79.

Thouret, J.-C. 1990. Effects of the November 131985 eruption on the snowpack and ice cap of Nevado del Ruiz volcano, Columbia. J. Volcan. Geotherm. Res., 41(1-4), 177-201.

Thouret, J.-C., R. Salinas and A. Murcia. 1990a. Eruption and masswasting-induced processes during the late Helocene destructive phase of Nevado del Ruiz volcano, Colombia. J. Volcan. Geotherm. Res., 41(1-4), 203-224.

Thouret, J.-C., J.-M. Cantagrel, R. Salinas and A. Murcia. 1990b. Quaternary eruptive history of Nevado del Ruiz (Colombia). J. Volcan. Geotherm. Res., 41(1-4), 225-251.

Thouret, J.-C., J.-M. Cantagrel, C. Robin, A. Murcia, R. Salinas and H. Cepeda. 1995. Quaternary eruptive history and hazard-zone model at Nevado del Tolima and Cerro Machin volcanoes, Colombia. 66(1-4), 397-426.

Thouret, J.-C. and 7 others. 2007. Volcano-glacier interactions on composite cones and lahar generation: the Nevado del Ruiz (Colombia) case study. Ann. Glaciol., 45, 115-127.
Walder, J.S. 2000. Pyroclast/snow interactions and thermally driven slurry formation. Part 1: theory for monodisperse grain beds. Bull. Volcanol., 62(2), 105-118.

Williams, S.N. ed. 1990a. Nevado del Ruiz Volcano, Columbia I. J. Volcan. Geotherm. Res. 41 (Special Issue)

Williams, S.N. ed. 1990b. Nevado del Ruiz Volcano, Columbia II. J. Volcan. Geotherm. Res. 42 (Special Issue.)

\section{APPENDIX}

After several hundred years without recorded eruption activity, Nevado del Huila began to erupt on 19 February 2007. After this initial eruption, mainly consisting of ash fall, a fissure opening with strong fumarolic activity in the Pico Central and Sur area was observed. Another eruption was recorded on 18 April 2007. Both eruptions were accompanied by floods and debris flows in the PÃez River. Five thousand people were evacuated and, fortunately, no major damage was caused. The mechanism of flow generation is not yet understood but may be related to the release of water reservoirs and the processes of snow and ice melting. The recent developments at Nevado del Huila confirm the large hazards associated with this volcano, as outlined in this paper, and underline the importance of monitoring and assessment efforts. 